American Journal of Economics and Business Administration 2 (1): 103-112, 2010

ISSN 1945-5488

(C) 2010 Science Publications

\title{
Measuring Investors' Reaction to the Adoption of International Financial Reporting Standards in Greece, Using a Market-Based Model
}

\author{
Athanasios Vazakidis and Stergios Athianos \\ Department of Applied Informatics, University of Macedonia, \\ 156 Egnatia Str, P.O. Box 1591540 06, Thessaloniki, Greece
}

\begin{abstract}
Problem statement: The aim of this study is to highlight the main differences between International Accounting Standards and Greek accounting, The sample constituted by 90 randomly selected Greek companies which are listed in Athens Stock Exchange were scrutinized concerning the differences in financial figures which have been appeared due to the adoption of IFRS. Approach: The use of capital asset pricing model has been inserted in a single regression model in order to depict the association of risk and the actual price return. The first model has been changed in order to exclude variables that were not statistically significant for the analysis. Finally, a revised model has been constructed and its statistically predictive power has been reexamined. Results: The outcome of the study postulates that when investors take into consideration the risk profile of each company, the differences in the valuation, current assets, current liabilities and sales can predict the share prices within a period of six months. Finally, there is evidence that the differences in valuation of the above companies, along with the classic CAPM can explain the fluctuations in share prices concerning the examined period. Conclusion: Since the field of Investigation is Greece, the research provided key differences between the old Greek conservative accounting and the fair value accounting of IFRS using a mixture of studies, the current paper has proved that the switch of the accounting regime from Greek accounting to IFRS has affected the valuation of companies. The above difference in the valuation has been taken into consideration by investors to readjust their portfolios.
\end{abstract}

Key words: Adoption of IFRS, CAPM, investors' reaction, z-score, Greek accounting

\section{INTRODUCTION}

Traditionally, the profession of accountancy in Greece was related to tax authorities. Baring in mind that the development of the accounting theory and the Greek accounting methods were influenced mainly through laws like the Commercial Law and $2190 / 1920$, which is about incorporated companies, accountants' aim were to prepare the accounting books in order to be audited by tax authorities. The interventions of tax legislations and the old law of 1920 along with the taste of the management of each company to obscure taxable capacity infracted the accounting principles and adulterated financial statements (Brugge, 1963).

After the entry of Greece in European Union and with the escalating competition among European and international companies, became more sensible that accounting is not only for tax purposes but also to contribute efficiently to better management of companies. Before this research proceeds to the examination of International Accounting Standards, it is crystal clear that a closer look to the abandoned Greek accounting based on General Accounting Plan has to be done in order to understand why Greece and other European countries had implemented IFRS.

Literature review: Bearing in mind that IFRS requires more disclosure of the companies, scholars studied the relationship between the disclosure practices and the firm's cost of equity. Botosan (2006) studied the relevant literature and concluded that the opinions of scholars concerning the problem at hand are confused. In general, when company is more transparent in its financial statements then the information asymmetry between investors and company is reduced and consequently the cost of equity is declined too. In accordance with the above notion, Daske (2006) scrutinized a sample of German companies which from the period 1993-2002 have adopted International Accounting Standards or US GAAP. Using a Residual income model and an Abnormal Earnings Growth

Corresponding Author: Athanasios Vazakidis, Department of Applied Informatics, University of Macedonia, 156 Egnatia Str, P.O. Box 1591540 06, Thessaloniki, Greece Tel: +302310 891863 
Am. J. of Economics and Business Administration 2 (1): 103-112, 2010

Model, Daske has proved that in fact the transition from local German GAAP to IAS has raised the equity's cost of capital. Daske postulated that the underlying reason for the above discrepancy was that the investors probably confused by the increasing disclosure of International Standards and therefore the judgments concerning the risk of the companies and consequently the cost of the equity was faded by the fact that there was no prior evidence about the transition. So the increased transparency from German companies led to an increase in information asymmetry. In contrast to Daske's research, Lambert et al. (2007) used an extended version of CAPM which compromised future cash flows. Building the above model, the covariance which is the crucial component of CAPM has been changed in order to detect investors' beliefs about the future cash flows of the company. This extend version of CAPM was expressed mathematically as follows:

$$
\mathrm{E}(\mathrm{R} \mid \Phi)=\mathrm{Rf}+\frac{\mathrm{E}(\mathrm{Rm} \mid \Phi)-\mathrm{Rf}}{\operatorname{Var}(\mathrm{Rm} \mid \Phi)}[\operatorname{CovR}, \mathrm{Rm} \mid \Phi]
$$

It becomes from the above expression that the crucial changed of the initial CAPM model is the insert of the variable $\Phi$ which represents the company's future cash flow. In the above case the $\beta$ is expressed with the function [CovR, Rm $\mid \Phi]$. With the use of the above model, Lambert et al. (2007) stated that the increasing accounting disclosure has declined the cost of equity which expressed with future cash flows. In consistent with the previous study, Karamanou and Nischiotis (2005) used a sample of 564 firms which adopt voluntary IAS. The examinations of events prior and after the announcement of the adoption were their first priority. The classic event study depicted that there was a statistical significance correlation between the adoption of IFRS and the company's cost of capital. The increased disclosure of the firms which were in their sample led to a tremendous decline in the cost of capital. It is worth to mention, that for the above study the Tobin's q was used in order to determine the company's cost of equity.

Having examined the above literature, it is crucial to mention that the company's cost of capital, which is the minimum return that a company should achieve in order not to decline the market value of its stocks, is the key to the implementation of financial models such as the internal rate of return or the net present value. Moreover the calculation of company's cost of capital is necessary for not only the valuation of the whole firm but also for the valuation of the stocks that a company has issued. Therefore the company's cost of capital should be treated as the level of risk that investors attribute to the firm, Taggart (1991).
Table 1: Number of companies and the sector of each company

\begin{tabular}{lcc}
\hline Sector & $\begin{array}{c}\text { Number of } \\
\text { companies }\end{array}$ & Percentage \\
\hline Construction and materials & 6 & 6.67 \\
Retail & 5 & 5.56 \\
Insurance & 1 & 1.11 \\
Basic resources & 7 & 7.78 \\
Personal and household goods & 12 & 13.33 \\
Technology & 5 & 5.56 \\
Banks & 9 & 10.00 \\
Travel and leisure & 4 & 4.44 \\
Media & 5 & 5.56 \\
Health care & 4 & 4.44 \\
Food and beverage & 17 & 18.89 \\
Industrial good and services & 9 & 10.00 \\
Utilities & 1 & 1.11 \\
Oil and gas & 2 & 2.22 \\
Chemicals & 3 & 3.33 \\
Total & 90 & 100.00 \\
\hline
\end{tabular}

Data: Data were obtained from Athens Stock Exchange. In order to avoid self selection and bias in the sample, 90 companies have been chosen randomly from the ASE. The initial sample was 120 companies but after the examination of their annual reports, some companies were excluded from the sample. The main reason for the above was the fact that many corporations in Greece which are listed in the Athens Stock Exchange do not end their fiscal year at 31 of December. Also, companies which were their first time that their shares went public were excluded from the sample in order to avoid further discrepancies (The law $2190 / 1920$ give the opportunity to new founded companies to extend their fiscal year beyond 12 months). Table 1 presents the number of companies and the sector of each company which was randomly selected for the sample. Moreover the daily closing prices for the above shares were obtained from Athens Stock Exchange in order to avoid any errors and manipulations. The time pattern span, from 31/12/200531/12/2006.

\section{MATERIALS AND METHODS}

The whole structure of the methodology could be seen as a mixture of the two waves concerning the adoption of IFRS. The value relevance and the cost of capital were basically mixed together in order to depict a regression model that will be able to reflect the impact of adoption in Greece.

The time frame is as follows: From 30/12/2005$30 / 6 / 2006$ the analysis will focus on the daily closing share prices of the sample corporations in order to calculate the expected returns based on the capital asset pricing model. From 30/12/2005-29/12/2006 (end of the fiscal year) the study will reveal the annual actual 
return for each share price. The purpose of the above separation has been made in order to depict the impact of the annual publication of reconciliations concerning the figure in the balance sheet and in the income statement.

Based on the Discriminant function, Altman (1968) Z-score was applied in order to calculated a value (the well known z-score) for each company. Z-score used to separate the healthy companies from those which were under bankruptcy. The function of Altman's Z-score is as follows:

$Z=0.012 \times 1+0.014 \times 2+0.033 \times 3+0.006 \times 4+0.999 \times 5$

where the variables of $\mathrm{x}$ are calculated with the next ratios:

- $\quad \mathrm{x} 1$ : Working capital/total assets

- $\quad \mathrm{x} 2$ : Retained earnings/total assets

- $\quad \mathrm{x} 3$ : Earnings before interest and taxes/total assets

- $x 4$ : Market value of the equity/total debt

- $x$ : Sales/total assets

The predictors are based on key figures of balance sheet and income statement. The above makes the model more historical, however the variable $\mathrm{x} 4$ which compromises the impact of the market value makes $\mathrm{Z}$ score a powerful prediction tool.

Based on the market value variable on Altman's Z score, if the original function rearranged, the total market value of a corporation can be calculated as follows (Thavikulwat, 2004):

$$
\begin{aligned}
& \text { Value }=\frac{\text { Zscore } * \text { Total_Debt }}{0.006}-0.012 \times 1 \\
& -0.014 \times 2-0 ., 033 \times 3-0.999 \times 5
\end{aligned}
$$

Until so far the methodology examined 2 variables that will crucial to the construction of model that will depict the magnitude of the impact. But how exactly the above figures was been calculated? The Capital Asset Pricing Model according to Sharpe (1964) and Lintner (1965) can be calculated by the following equation:

$$
\mathrm{E}(\mathrm{RI})=\mathrm{RF}+\beta[\mathrm{E}(\mathrm{rm})-\mathrm{RF}]
$$

The methodology accepted that the risk free rate can be derived from a Government bond of 10 year maturity. According to the Bank of Greece, the above bond returns $4.58 \%$ (http://eng.bankofgreece.gr/en/statistics/).
To sum up, until so far the analysis focused on basic calculations that have been made in order to evaluate the expected return of each company in the sample based on CAPM and the total value for the above sample based on Z-score . While, the CAPM is able to describe the cost of capital for each company, it can be also seen as the minimum expectation of investors concerning each company's share price return (Botosan, 2006). If we accept the term minimum, then CAPM will leave space for investors to adjust their portfolios not only according to the risk profile of each company but also to other factors that can not be compromised in the CAPM. According to the above the first hypothesis is:

H1: The actual return of a share price differs from the expected return based on CAPM

Taking into consideration the researches that have shown the impact of adoption of IFRS in financial statements and in the cost of capital, the analysis expect that the above readjustments in financial figures, as the value relevance literature postulates, have major impact in investors' beliefs. Therefore the second hypothesis can be written as follows:

H2: The difference between the expected return of each share and the actual return based on the period 31/12/2005-29/12/2006 is correlated with the percentage difference in total valuation of a company

If we accept that not only the total valuation of a company plays critical role in investors judgments but also crucial Figures of the balance sheet and income statement which can be used from investors to perform a financial statements analysis based on key financial ratios, then the impact of IFRS in total assets, total liabilities, current assets, currents liabilities and sales can affect investors' perspectives

H3: The difference between the expected return of each share and the actual return is correlated with the percentage differences in total assets, total liabilities, current assets, current liabilities and sales

Finally, it is proven from other researches that companies which adopt voluntary the International Accounting Standards or compiled financial statements both with National GAAP and other accounting systems which are based on fair value accounting such as US GAAP, prepare investors for the convergence in 
accounting regimes. Armstrong et al. (2009) examined information prior to the adoption of IFRS in Europe. Sixteen events concerning the announcements of IASB have been scrutinized in order to depict the impact in investors' beliefs. Having used a regression model with dummy variables such as the Information Quality Factor, the research proved that investors took into consideration the above events. Concerning the fact that many companies in Europe do not provide enough disclosures in their financial statements, the study has shown that the IFRS adoption helped the above companies to decrease the information asymmetry. In the same line with the above study, we expect that companies which provide any information concerning the adoption of IFRS in Greece or their shares are listed to Stock Exchange Market except from ASE's prior to the mandatory adoption, will affect investors decisions.

H4: The difference between the expected return of a share and the actual return is strongly correlated with any prior information that has been given by companies to the investor community

Before the analysis proceeds to the final construction of the model, it is worth to mention that the factor of actual return for each share has been calculated as follows:

$$
\mathrm{AR}=\mathrm{LN}\left(\frac{\text { CL.P }}{\text { CL.P }}\right)
$$

Taking the hypotheses and the previous mentioned calculations for CAPM and Total valuation into consideration the final model is as follows:

$$
\begin{aligned}
& \mathrm{AR}(\mathrm{i})-\mathrm{E}(\mathrm{Ri})=\alpha+\beta \Delta \mathrm{TV}+\beta_{1} \Delta \mathrm{TA}+ \\
& \beta_{2} \Delta \mathrm{CA}+\beta_{3} \Delta \mathrm{TL}+\beta_{4} \Delta \mathrm{CL}+\beta_{5} \Delta \mathrm{S}+\beta_{6} \mathrm{PR} . \mathrm{INF}+\varepsilon
\end{aligned}
$$

where, AR(i)-E (Ri) indicates the difference between the expected return and the actual return of a share. The Greek letter $\Delta$ in front of Total Valuation (TV), Total Assets (TA), Current Assets (CA), Total Liabilities (TL), Current Liabilities (CL), Sales (S) and PR. INF (Prior information) depicts the percentage difference based on the adoption of IFRS. The letter $\varepsilon$ is the error term of the linear regression.

The next part of the analysis will focus on the results of the statistical analysis. Moreover the comparison of the outcome of the study with other papers and possible limitations and implications will be discussed.

\section{RESULTS}

In order to depict the key differences between International Accounting Standards and the Greek accounting the analysis focus on arithmetic mean of basic Figures on the balance sheet and income statement. Table 2 highlights basic descriptive statistics for both Greek accounting and International Accounting Standards. As is it clearly observed, the arithmetic mean of total assets, total liabilities, current assets and current liabilities is higher under International Accounting Standards than Greek GAAP. Bearing in mind that Greece according to its accounting system can be characterized as a code law country (like German and France); its accounting system is based on historical cost. Therefore, the conservatism of Greek accounting is depicted to the above results of statistical analysis. The fair value notion of IFRS where the valuation of assets is done in current values is the main cause for the above differences in the arithmetic means. The results below are consistent with the findings of Dimitropoulos and Asteriou (2008) who found that the conservatism in Greek accounting practices have been increased from 1995-2004.

H0: The arithmetic mean of Total assets, total liabilities, current assets current liabilities, sales and earnings before taxes under Greek GAAP is the statistically the same under IFRS

The above hypothesis can be written as:

$$
\text { H0: M.gr }=\text { M.ifrs }
$$

The alternative hypothesis is:

$$
\text { H1: M.gr } \neq \text { M.ifrs }
$$

Table 3 highlights the results for the independent. T-test for the above hypothesis.

The t-test has two directions. In the first direction the test suggests that the variances between the sample of Greek accounting and the sample of IFRS are equal. The second direction presupposes exactly the opposite. Using the test of Lavene which controls the above assumptions and checks the hypothesis of equal variances, the results depict that the hypothesis of equal variances for all cases is accepted ( $p$-value $=$ Sig $>0.05$ ). Moreover the results indicate that the differences in arithmetic means for all cases are not statistically different since the significance (2-tailed) level for all cases are over 5\%. Thus in the current case we accept the null hypothesis that the means of the above accounting figures are statistically the same. 
Am. J. of Economics and Business Administration 2 (1): 103-112, 2010

Table 2: Group statistic

\begin{tabular}{lllrrr}
\hline Accounting regime & & N & Mean & Std. deviation & Std. error mean \\
\hline Total assets in & IFRS & 90 & 2515.9538 & 8064.43629 & 850.06622 \\
millions & GRGAAP & 90 & 2442.6878 & 7881.69935 & 830.80406 \\
Total liabilities in & IFRS & 90 & 2210.2899 & 7566.41010 & 797.56965 \\
millions & GRGAAP & 90 & 2131.4604 & 7406.47221 & 780.71072 \\
Current assets & IFRS & 90 & 2138435.0000 & 7756290.88800 & 8175848.00000 \\
in thousands & GRGAAP & 90 & 2112723.0000 & 7590105.39900 & 800067.40000 \\
Current liabilities & IFRS & 90 & 609839.1000 & 2059164.36900 & 217055.00000 \\
in thousands & GRGAAP & 90 & 549231.3000 & 1917375.04300 & 202109.10000 \\
Sales in millions & IFRS & 90 & 462.0656 & 936.29891 & 98.69457 \\
& GRGAAP & 90 & 464.0823 & 927.98602 & 97.81832 \\
Earnings B. taxes & IFRS & 90 & 41778.5700 & 116759.92498 & 12307.58000 \\
N thousands & GRGAAP & 90 & 42076.1000 & 121431.63898 & 12800.02000 \\
\hline
\end{tabular}

Table 3: Independent samples test

\begin{tabular}{|c|c|c|c|c|c|c|c|c|c|c|}
\hline & & \multirow{2}{*}{\multicolumn{2}{|c|}{$\begin{array}{l}\text { Levence's } \\
\text { test for } \\
\text { equality of } \\
\text { variances }\end{array}$}} & \multicolumn{7}{|c|}{ T-test for equality of means } \\
\hline & & & & \multirow[b]{2}{*}{$\mathrm{t}$} & \multirow[b]{2}{*}{$\mathrm{di}$} & \multirow[b]{2}{*}{$\begin{array}{l}\text { Sig. } \\
\text { (2-tailled) }\end{array}$} & \multirow[b]{2}{*}{$\begin{array}{l}\text { Mean } \\
\text { difference }\end{array}$} & \multirow[b]{2}{*}{$\begin{array}{l}\text { Std. error } \\
\text { difference }\end{array}$} & \multicolumn{2}{|c|}{$\begin{array}{l}95 \% \text { confidence of the } \\
\text { difference interval }\end{array}$} \\
\hline & & $\mathrm{F}$ & Sig. & & & & & & Lower & Upper \\
\hline \multirow[t]{2}{*}{ Total assets } & $\begin{array}{l}\text { Equal variances } \\
\text { Assumed }\end{array}$ & 0.011 & 0.917 & 0.062 & 178.000 & 0.951 & 73.26604 & 1188.63280 & -0072.360 & 2418.89100 \\
\hline & $\begin{array}{l}\text { Equal variances } \\
\text { not assumed }\end{array}$ & & & 0.062 & 177.907 & 0.951 & 73.26604 & 1188.63280 & -2272.370 & 2418.90000 \\
\hline \multirow[t]{2}{*}{ Total liabilities } & $\begin{array}{l}\text { Equal variances } \\
\text { Assumed }\end{array}$ & 0.013 & 0.908 & 0.071 & 178.000 & 0.944 & 78.82955 & 1116.07640 & -2123.610 & 2281.27300 \\
\hline & $\begin{array}{l}\text { Equal variances } \\
\text { not assumed }\end{array}$ & & & 0.071 & 177.919 & 0.944 & 78.82955 & 1116.07640 & -2123.620 & 2281.28000 \\
\hline \multirow[t]{2}{*}{ Current assetes } & $\begin{array}{l}\text { Equal variances } \\
\text { Assumed }\end{array}$ & 0.003 & 0.954 & 0.022 & 178.000 & 0.982 & 25711.90100 & 1143919.90000 & -2231678.000 & 2283102.00000 \\
\hline & $\begin{array}{l}\text { Equal variances } \\
\text { not assumed }\end{array}$ & & & 0.022 & 177.917 & 0.982 & 25711.90100 & 1143919.90000 & -2231685.000 & 02283109.00000 \\
\hline \multirow[t]{2}{*}{ Current liabilities } & $\begin{array}{l}\text { Equal variances } \\
\text { Assumed }\end{array}$ & 0.145 & 0.704 & 0.204 & 178.000 & 0.838 & 60607.71200 & 296582.10000 & -524662.000 & 645877.20000 \\
\hline & $\begin{array}{l}\text { Equal variances } \\
\text { not assumed }\end{array}$ & & & 0.204 & 177.102 & 0.838 & 60607.71200 & 296582.10000 & -524682.000 & 645897.50000 \\
\hline \multirow[t]{2}{*}{ Sales } & $\begin{array}{l}\text { Equal variances } \\
\text { Assumed }\end{array}$ & 0.000 & 0.986 & -0.015 & 178.000 & 0.988 & -2.01670 & 138.95698 & -276.232 & 272.19834 \\
\hline & $\begin{array}{l}\text { Equal variances } \\
\text { not assumed }\end{array}$ & & & -0.015 & 177.986 & 0.988 & -2.01670 & 138.95698 & -276.232 & 272.19849 \\
\hline \multirow[t]{2}{*}{ Earnings B. taxes } & $\begin{array}{l}\text { Equal variances } \\
\text { Assumed }\end{array}$ & 0.008 & 0.927 & -0.017 & 178.000 & 0.987 & -297.53092 & 17757.16500 & -35339.200 & 34744.12000 \\
\hline & $\begin{array}{l}\text { Equal variances } \\
\text { not assumed }\end{array}$ & & & -0.017 & 177.727 & 0.987 & -297.53092 & 17757.16500 & -35339.600 & 34744.49000 \\
\hline
\end{tabular}

Table 4: Group statistic

\begin{tabular}{llllll}
\hline $\begin{array}{l}\text { Accounting } \\
\text { regime }\end{array}$ & & $\mathrm{N}$ & Mean & $\mathrm{SD}$ & $\begin{array}{l}\text { Std. error } \\
\text { mean }\end{array}$ \\
\hline & IFRS & 90 & 0.8099069 & 0.81370869 & 0.08577243 \\
ZSCORE & GRGAAP & 90 & 0.8598150 & 0.81374219 & 0.08577596 \\
\hline
\end{tabular}

Comparing the above results with prior researches in the problem at hand, the analysis reveals some discrepancies. Stergios et al. (2004), having examined a sample of 40 Greek companies which adopted voluntary the IFRS, found that the arithmetic mean of total assets and total liabilities was statistically different. However the case was the same for earnings and sales. In both studies the arithmetic mean of the above is statistically the same. Nevertheless, the outcome for both studies is the same.
IFRS under the regime of fair value accounting, evaluates with current prices the Figures in the balance sheet which entails higher prices for fair value than the conservative Greek accounting. The differences in the independent T-test can be possibly occurred by the fact that the one study used data prior to the adoption and the current dissertation after the mandatory adoption.

Before the analysis proceeds to the statistical test of the regression model, it would have been great omission if the results of Z-score had not been scrutinized.

Table 4 represents the arithmetic mean for Altman's $\mathrm{Z}$ score under IFRS and under Greek accounting. 
Am. J. of Economics and Business Administration 2 (1): 103-112, 2010

Table 5: Independent samples test

\begin{tabular}{|c|c|c|c|c|c|c|c|c|c|}
\hline & \multicolumn{2}{|c|}{$\begin{array}{l}\text { Levine's test } \\
\text { for equality } \\
\text { variances }\end{array}$} & \multicolumn{7}{|c|}{ T-test for equality of means } \\
\hline & \multirow[b]{2}{*}{$\mathrm{F}$} & \multirow[b]{2}{*}{ Sig } & \multirow[b]{2}{*}{$\mathrm{t}$} & \multirow[b]{2}{*}{ di } & \multirow[b]{2}{*}{ Sig. (2-tailed) } & \multirow{2}{*}{$\begin{array}{l}\text { Mean } \\
\text { Difference }\end{array}$} & \multirow{2}{*}{$\begin{array}{l}\text { Std. error } \\
\text { difference }\end{array}$} & \multicolumn{2}{|c|}{$\begin{array}{l}95 \% \text { confidence of the } \\
\text { difference }\end{array}$} \\
\hline & & & & & & & & Lower & Upper \\
\hline $\begin{array}{l}\text { ZSCORE } \\
\text { Equal variances } \\
\text { assumed }\end{array}$ & 0.035 & 0.851 & -0.411 & 178.000 & 0.681 & -0.04990809 & 0.12130303 & -0.289285 & 0.18946899 \\
\hline $\begin{array}{l}\text { Equal variances } \\
\text { not assumed }\end{array}$ & & & -0.411 & 178.000 & 0.681 & -0.04990809 & 0.12130303 & -0.289285 & 0.18946899 \\
\hline
\end{tabular}

Table 6: Modal summary

\begin{tabular}{|c|c|c|c|c|c|c|c|c|c|c|}
\hline \multirow[b]{2}{*}{ Model } & \multirow[b]{2}{*}{$\mathrm{R}$} & \multirow[b]{2}{*}{$\mathrm{R}^{2}$} & \multirow[b]{2}{*}{$\begin{array}{l}\text { Adjusted } \\
\mathrm{R}^{2}\end{array}$} & \multirow[b]{2}{*}{$\begin{array}{l}\text { Std. error of } \\
\text { the estimate }\end{array}$} & \multicolumn{5}{|c|}{ Change statistics } & \multirow[b]{2}{*}{$\begin{array}{l}\text { Durbin- } \\
\text { Watson }\end{array}$} \\
\hline & & & & & $\begin{array}{l}\mathrm{R}^{2} \\
\text { change }\end{array}$ & F change & df1 & df 2 & Sig. F change & \\
\hline 1 & 0.738 & 0.545 & 0.506 & 0.20436035 & 0.545 & 14005 & 7 & 82 & 0.000 & 2.198 \\
\hline
\end{tabular}

It becomes crystal clear that under International Accounting Standards the probability for a company to fail is lower than Greek accounting. The reason for the above difference is probably occurred from the higher values of total assets and total liabilities that are recognized based on the fair value accounting. The underlying assumption of the above should be the decrease in the information asymmetry between corporations and investors. Unfortunately, the analysis did not detect such analysis in recent literature concerning the impact of IFRS in the prediction of failures. Nevertheless, it is worth to observed that the arithmetic mean both for International Accounting Standards and Greek accounting is statistically the same as the Table 5 highlights, 2 tailed significance level over 0,05. Moreover, bearing in mind the Altman's threshold for the prediction of bankruptcy, where the results of $\mathrm{z}$-score can be interpreted as (Calandro, 2007):

- If $Z>2.99$ then the firm is not at risk of distress, Safe zone

- If $\mathrm{Z}<1.88$ then the firm will probably go bankrupt, Distress zone

- If $1.88 \leq \mathrm{Z} \leq 2.99$ then the firm is at risk of financial distress, Grey zone

The most Greek corporations in the sample are on Distress zone. In fact the above outcome is aligned with the economic condition that exists in Greece the last 3 decades.

The last part of the statistical analysis is going to analyze the results from the proposed linear regression model and will provide comparisons from other researches. Bearing in mind the proposed model:

$$
\begin{aligned}
& \mathrm{AR}(\mathrm{i})-\mathrm{E}(\mathrm{Ri})=\alpha+\beta \Delta \mathrm{TV}+\beta_{1} \Delta \mathrm{TA}+\beta_{2} \Delta \mathrm{CA}+\beta_{3} \Delta \mathrm{TL} \\
& +\beta_{4} \Delta \mathrm{CL}+\beta_{5} \Delta \mathrm{S}+\beta_{6} \mathrm{PR} . \mathrm{INF}+\varepsilon
\end{aligned}
$$

The first statistical term that should have been examined was the $\mathrm{r}^{2}$.

Table 6 presents the first results of the regression model. The value $\mathrm{R}$ denotes the absolute value for the coefficient of linear correlation. However the value $\mathrm{R}^{2}$, which is the square of the absolute value of $\mathrm{R}$, measures the proportion or the percentage of the whole variability of dependent variable which is explained from the multiple regression model. In the above case, the total independent variables can explain $54.5 \%$ of the fluctuation of the dependent variable. The regression's coefficient $\mathrm{R}$ square denotes that the higher is the value of $\mathrm{R}$ squares the better for the line of regression to be adjusted in the data. It is worth to mention that a lower value for $\mathrm{R}^{2}$ do not denote necessarily lack of correlation between the dependent and independent variables. It can be a strong relation but not a linear one. Bearing in mind that the current research is done in the field of accounting, the value of $\mathrm{R}^{2}$ can be seen as quite strong. Moreover the level of $\mathrm{F}$ test along with its significance level ( $\mathrm{p}$-value $<5 \%$ ) provide another evidence for the predictive value of independent variables. Finally, the last statistic of Durbin-Watson which measures one of the basic assumptions of the multiple regressions is quite sufficient (around 2). 
Am. J. of Economics and Business Administration 2 (1): 103-112, 2010

Table 7: ANVOA $^{\mathrm{b}}$

\begin{tabular}{lllllll}
\hline Mode & & Sum of Squares & df & Mean Square & F & Sig. \\
\hline 1 & Regression & 4.094 & 7 & 0.585 & 14.005 & $0.000^{\mathrm{a}}$ \\
& Residual & 3.425 & 82 & 0.042 & & \\
& Total & 7.519 & 89 & & & \\
& & & & & & \\
\hline
\end{tabular}

a: Predictors: (Constant), diff valuation, diff tot asset, prior infor, diff; Cur liabili, differ sales, diff cur assets, diff tot debt; b: dependent variable: AR (i)-E (RI)

Table 8: Coefficients ${ }^{\mathrm{a}}$

\begin{tabular}{|c|c|c|c|c|c|c|c|}
\hline \multirow[b]{2}{*}{ Model } & \multicolumn{2}{|c|}{ Unstandardized coefficients } & \multicolumn{2}{|c|}{$\begin{array}{l}\text { Standardized } \\
\text { coefficients }\end{array}$} & \multirow[b]{2}{*}{ Sig } & \multicolumn{2}{|c|}{ Collinearity Statistics } \\
\hline & B & Std. error & $\begin{array}{l}\text { coemric } \\
\text { Beta }\end{array}$ & $\mathrm{t}$ & & $\begin{array}{l}\text { Collinearit } \\
\text { Tolerance }\end{array}$ & VIF \\
\hline (Constant) & 0.44 & 0.042 & & 1.044 & 0.299 & & \\
\hline DIFF CUR ASSETS & -0.408 & 0.187 & -0.204 & -2.185 & 0.032 & 0.637 & 1.570 \\
\hline DIFF CUR LIABILI & -0.167 & 0.129 & -0.114 & -1.298 & 0.198 & 0.719 & 1.391 \\
\hline DIFF TOT ASSET & -0.321 & 0.435 & -0.149 & -0.737 & 0.463 & 0.135 & 7.400 \\
\hline DIFF TOT DEBT & 0.539 & 0.419 & 0.279 & 1.286 & 0.202 & 0.118 & 8.504 \\
\hline DIFFER SALES & 1.401 & 0.474 & 0.372 & 2.955 & 0.004 & 0.351 & 2.847 \\
\hline PRIOR INFOR & 0.051 & 0.051 & 0.086 & 1.006 & 0.317 & 0.763 & 1.311 \\
\hline DIFF VALUATION & 1.018 & 0.354 & 0.467 & 2.878 & 0.005 & 0.211 & 4.743 \\
\hline
\end{tabular}

Table 9: Modal summary

\begin{tabular}{lllllllllll}
\hline & & \multicolumn{1}{c}{ Change statistics } \\
Model & $\mathrm{R}$ & $\mathrm{R}^{2}$ & $\begin{array}{l}\text { Adjusted } \\
\mathrm{R}^{2}\end{array}$ & $\begin{array}{l}\text { Std. error of } \\
\text { the estimate }\end{array}$ & $\begin{array}{l}\mathrm{R}^{2} \\
\text { change }\end{array}$ & F change & df1 & df2 & Sig. F change & Durbin-Waston \\
\hline 1 & 0.727 & 0.529 & 0.506 & 0.20419168 & 0.529 & 23.833 & 4 & 85 & 0.000 & 2.174 \\
\hline
\end{tabular}

a: Predictors: (constant), diff cur liabili, diff valuation, diff cur assets, differ sales; b: Dependent variable: AR(i)-E(Ri)

Table 10: ANVOA $^{\mathrm{b}}$

\begin{tabular}{|c|c|c|c|c|c|c|}
\hline Mod & & $\begin{array}{l}\text { Sum of } \\
\text { squares }\end{array}$ & $\mathrm{df}$ & $\begin{array}{l}\text { Mean } \\
\text { squares }\end{array}$ & $\mathrm{F}$ & sig. \\
\hline \multirow[t]{3}{*}{1} & Regression & 3.975 & 4 & 0.994 & 23.833 & $0.000^{\mathrm{a}}$ \\
\hline & Residual & 3.544 & 85 & 0.042 & & \\
\hline & Total & 7.519 & 89 & & & \\
\hline
\end{tabular}

a: Predictors: (Constant), DIFF CUR LIABILI, DIFF valuation, DIFF CUR assets, differ sales; b: Dependent variable: AR(i)-E(Ri)

It is worth to mention that the Durbin-Watson indicates the assumption of residuals independence. The above means that the regression model presupposes that all the pairs of residuals have covariance equal to zero. However the high value of $\mathrm{R}^{2}$ do not necessary means that the above model is well fitted concerning the sample. In order to have a more clear aspect for the independent variable, the analysis will follow the ANOVA test, which is based on the F distribution.

Table 7 indicates the results for the $\mathrm{F}$ test. Using the Table 7 , it can be easily extracted that the possibility of all the independent variables in the regression model to be zero is very small since the significance level is below 0.05 . It is worth to mention that the number 4.094 indicates the variance which is explained from the regression model and the 7.519 highlights the total variance of the data set. The difference between the above numbers is the variance which is not explained by the model. However the most crucial result from the regression analysis, expect from
$\mathrm{R}^{2}$, is the analysis of the $\beta$ coefficients. The examination of the above results will highlight the validation of the hypotheses.

Table 8 presents the results for beta coefficients of the regression model. Scrutinizing the Table 8, the analysis reveals that the variables of $\Delta \mathrm{TA}$ (percentage difference in total assets), $\Delta \mathrm{TL}$ (percentage difference in total liabilities) and Prior information are not statistically significant for the regression model since their significance level is higher than the accepted $\mathrm{p}$ value (0.05). The above can also be concluded if we control the regression analysis for the Variation Inflation Factor. One of the most problems in the multiple regressions is the multicollinearity. The above problem appears when an independent variable is correlated with another independent factor. Therefore, through the use of the one variable the other independent variable can be explained. Thus, the existence of the above variables can not be inserted into the regression model. The Variation Inflation Factor measures the above problem and when takes values higher than 5 signals the above problem (Steward, 1987). As it is clear from the Table 8 the variable of total assets and total debt should be excluded from the analysis. Bearing in mind that the significance level for prior information is 0.317 and the results from the VIF, the analysis run the regression from the beginning without the above factors. 
Am. J. of Economics and Business Administration 2 (1): 103-112, 2010

Table 11: Coefficients ${ }^{\mathrm{a}}$

\begin{tabular}{|c|c|c|c|c|c|c|c|c|}
\hline \multirow[b]{2}{*}{ Mode } & & \multicolumn{2}{|c|}{ Unstandardized coefficients } & \multicolumn{2}{|c|}{$\begin{array}{l}\text { Standardized } \\
\text { coefficients }\end{array}$} & \multirow[b]{2}{*}{ Sig. } & \multicolumn{2}{|c|}{ Collinearity statistics } \\
\hline & & B & Std. error & bête & $\mathrm{t}$ & & Tolerance & VIF \\
\hline \multirow[t]{5}{*}{1} & constant & 0.087 & 0.026 & & 3.287 & 0.001 & & \\
\hline & Differ sales & 1.104 & 0.336 & 0.293 & 3.285 & 0.001 & 0.697 & 1.434 \\
\hline & Diff valuation & 1.311 & 0.182 & 0.602 & 7.208 & 0.000 & 0.795 & 1.257 \\
\hline & Diff cur assets & -0.329 & 0.168 & -0.165 & -1.956 & 0.054 & 0.783 & 1.277 \\
\hline & Diff cur liable & -0.099 & 0.121 & -0.067 & -1.815 & 0.048 & 0.811 & 1.233 \\
\hline
\end{tabular}

a: Dependent variable: AR(i)-E(Ri)

The possible explanation for the above can be derived from the fact that the corporations in Greece which provide any information concerning the adoption of IFRS were very few in order to affect the whole sample. Another possible explanation concerning the exclusion of the variable PRI.INF is that possibly the information about the adoption of IFRS which provided from early adopters wan not have enough quality and quantity in order to affect investors. The above result is consistent with the dissertation's assumption concerning the fact that none investor have the appropriate information to readjust his portfolio prior to the adoption of IFRS The insignificance level of total assets and total liabilities is probably caused form the fact that the above accounting figures are more general in the balance sheet and do not reveal sufficient information for investors. Taking the above results into consideration, the regression model has been tested without the above variables.

Table 9-11 present the new results after the exclusion of the three mentioned variables. The predictive power of the model is declined barely to $52.90 \%$ and remains powerful. Moreover the significance level of the ANOVA Test is the same pvalue $<0.05$ and the $F$ statistic presented an increase up to 23.83. The most crucial part is the table of coefficients. After the exclusion of the three variables, the beta coefficients are all statistically significant under the rule of thumb $\mathrm{p}$-value $<0.05$. Last but not least the problems of multicollinearity have been resolved, since none variable has VIF beyond 2. After the rejection of hypothesis 4 and the revisit of hypothesis 3 the final equation that predicts the market reaction to the adoption of IFRS in Greece is as follows:

$$
\mathrm{AR}(\mathrm{i})-\mathrm{E}(\mathrm{Ri})=\alpha+\beta \Delta \mathrm{TV}+\beta_{1} \Delta \mathrm{CA}+\beta_{2} \Delta \mathrm{CL}+\beta_{3} \Delta \mathrm{S}+\varepsilon \mathrm{x}
$$

\section{DISCUSSION}

Unfortunately the comparison with other studies can not be done, since the current research is new in the field of accounting concerning the market reaction to the adoption of IFRS. Nevertheless, it can be seen as a contribution to the studies of the value relevance. Consistent with the above results, Bellas et al. (2007) found that the book values are more relevant under International Accounting Standards. The majority of the studies concerning the adoption of IFRS used the regression model where the independent variable is the share price and the independent variables are the book value of equity and the net income. In the same line with the above, Harris and Muller (1999) tested the same model using data from companies that passed from US GAAP to IFRS their findings suggest that indeed under International accounting regime the accounting numbers provide investors with more quality information about the fluctuation of the stock prices. The predictive value of their model when was controlled by the differences in the accounting numbers which were derived from the reconciliation Table was increased beyond $90 \%$. The apparent discrepancies among value relevant studies, concerning the predictive power of the model, are probably caused from the completely different data set. Nevertheless, the current study have depicted that when the share price is checked for its risk, the difference basically in the total valuation could be a crucial factor in order to determine its future fluctuation.

\section{CONCLUSION}

The recent regulation of European Union concerning the financial reporting across all European listed companies was the main inspiration of the current dissertation. The mandatory adoption of International Accounting Standards has fluttered the dovecotes of the accounting science. Information nowadays plays the most crucial role in the procedure of decision making. Investor community strives to find more qualitative information in order to adjust better its investment portfolios. Scholars around the world try to find out ways to move this new wane into the right direction. The aim is one and only one: Global convergence in accounting practices. Whether investors will take advantage of the above effort, it is a matter of time to be proved. The current study highlighted the above 
efforts of both IASB and academic community. Evidences from the history of accounting have proved that the process towards more sufficient information is time consuming. Moreover since the field of Investigation is Greece, the research provided key differences between the old Greek conservative accounting and the fair value accounting of IFRS using a mixture of studies, the current paper has proved that the switch of the accounting regime from Greek accounting to IFRS has affected the valuation of companies. The above difference in the valuation has been taken into consideration by investors to readjust their portfolios. The use of Capital Asset Pricing Model has been inserted in a single regression model in order to depict the association of risk and the actual price return. The first model has been changed in order to exclude variables that were not statistically significant for the analysis. Finally, a revised model has been constructed and its statistically predictive power has been reexamined. The outcome of the study postulates that when investors take into consideration the risk profile of each company, the differences in the valuation, current assets, current liabilities and sales can predict the share prices within a period of six months. However, since the current study is new in the academic literature, its findings were impossible to be compared with other studies. Further more the use of Capital Asset Pricing Model has proved that did not compromise many Figures in order to explain the beliefs of investors. Moreover the assumptions of CAPM along with the assumptions of the current study make the findings of the model powerless to fully explain the actual movements in the capital market. One more limitation of this study was the limited time horizon due to the fact that Greek companies provide only the first year of the mandatory adoption the reconciliation table. Last but not least as the current research focus on the Greek accounting, which from each nature is a conservative system, the findings can not be generalized in different countries where the accounting system is shareholder's oriented. Bearing in mind the above limitations, further researches can be done in other countries where the accounting system is stakeholder's oriented. This is vital to the countries that are concerning the adoption of IFRS Moreover the use of different financial tools is proposed in order to generalize the findings of the current study. The use of Weighted Average Cost of Capital and the Tobin's q can replace the CAPM and $\mathrm{Z}$ score respectively. Last but not least, the time of this study can be expanded to interim financial reports of the same year in order not only to examine more timely information but also to prevent creative accounting that can be possibly done by the management at the end of the year.

Facing the corporations like human beings, none financial research can highlight the complexity of their operations. Moreover it is difficult or impossible for a simple model to compromise factors that can affect the judgment of investors. Nevertheless, models, such as the proposed, can only be seen as simplifications of the real world.

\section{REFERENCES}

Altman, E., 1968. Financial ratios, discriminant analysis and the prediction of corporate bankruptcy. J. Finance, 23: 589-609.

Armstrong, S., E. Barth, A. Jagolinzer and E. Riedl, 2009. Market reaction to the adoption of I.F.R.S in Europe. Working Paper Series, Accounting Review forthcoming.

http://papers.ssrn.com/sol3/papers.cfm?abstract_id $=903429$

Bellas, A., T. Kanellosand and K. Papadatos, 2007. The consequences of applying international accounting Standards to the financial statements of Greek companies. Working paper, University of Patras. http://papers.ssrn.com/sol3/papers.cfm?abstract_id $=985048$

Botosan, C., 2006. Disclosure and the cost of capital: What do we know. Account. Bus. Res., 36: 31-40.

Brugge, W., 1963. The accountancy profession in Greece. Account. Rev., 38: 596-600.

Calandro, J., 2007. Considering the utility of Altman's $\mathrm{Z}$ score as a strategic assessment and performance management tool. Strat. Leadership, 35: 37-43.

Daske, H., 2006. Economic benefits of adopting IFRS or US-GAAP-Have the expected cost of equity capital really decreased. J. Bus. Finance Account., 33: 329-373.

Dimitropoulos, P. and D. Asteriou, 2008. Timeliness, conservatism and financial transparent firms under the Greek accounting setting. Rev. Account. Finance, 7: 252-269.

Harris, M. and K. Muller, 1999. The market valuation of IAS versus US GAAP accounting measures using form 20-F reconciliations. J. Account. Econ., 26: 285-312.

Karamanou, I. and G. Nischiotis, 2005. The valuation effects of firms voluntary adoption of international accounting standards. Working Paper, University of Cyprus.

http://papers.ssrn.com/sol3/papers.cfm?abstract_id $=676328$ 
Lambert, R., C. Leuz and R. Verrencchia, 2007. Accounting information, disclosure and the cost of capital. J. Account. Res., 45: 385-420.

Lintner, J., 1965. The valuation of risk assets and the selection of risky investments in stock portfolios and capital budgets. Rev. Econ. Stat., 47: 13-37.

Sharpe, W., 1964. Capital asset prices: A theory of market equilibrium under conditions of risk. J. Finance, 19: 425-442.

Steward, G., 1987. Collinearity and least squares regression. Stat. Sci., 2: 68-84.

Stergios, A., A. Vazakidis and N. Dritsakis, 2004. Financial statement effects of adopting international accounting standards. Working Paper Series, University of Macedonia. http://users.uom.gr/ drits/publications/Financial_St atement_Effects.pdf
Taggart, R., 1991. Consistent valuation and cost of capital expressions with corporate and personal taxes. J. Financ. Manage., 20: 8-20.

Thavikulwat, P., 2004. Determining the value of a firm. Dev. Bus. Simulat. Exp. Learn., 31: 210-215. 